Article

\title{
Influence of Time since Fire and Micro-Habitat Availability on Terricolous Lichen Communities in Black Spruce (Picea mariana) Boreal Forests
}

\author{
Saliha Zouaoui, Catherine Boudreault *, Pierre Drapeau and Yves Bergeron \\ Centre d'Étude de la Forêt and the Natural Sciences and Engineering Research Council, \\ UQAM-UQAT Industrial Chair in Sustainable Forest Management, Université du Québec à Montréal, \\ C.P. 8888, Succursale Centre-Ville, Montréal, QC, H3C 3P8, Canada; \\ E-Mails: saliha_zoua@hotmail.com (S.Z.); drapeau.pierre@uqam.ca (P.D.); \\ yves.bergeron@uqat.ca (Y.B.) \\ * Author to whom correspondence should be addressed; \\ E-Mail: boudreault.catherine@courrier.uqam.ca; Tel.: +1-514-987-3000; Fax: +1-514-987-1816.
}

External Editor: Eric J. Jokela

Received: 15 October 2014; in revised form: 3 November 2014 / Accepted: 11 November 2014 / Published: 18 November 2014

\begin{abstract}
Terricolous lichens are an important component of boreal forest ecosystems, both in terms of function and diversity. In this study, we examined the relative contribution of microhabitat characteristics and time elapsed since the last fire in shaping terricolous lichen assemblages in boreal forests that are frequently affected by severe stand-replacing fires. We sampled 12 stands distributed across five age classes (from 43 to $>200$ years). In each stand, species cover (\%) of all terricolous lichen species and species richness were evaluated within 30 microplots of $1 \mathrm{~m}^{2}$. Our results show that time elapsed since the last fire was the factor that contributed the most to explaining terricolous lichen abundance and species composition, and that lichen cover showed a quadratic relationship with stand age. Habitat variables such as soil characteristics were also important in explaining lichen richness. These results suggest that the presence of suitable substrates is not sufficient for the conservation of late-successional terricolous lichen communities in this ecosystem, and that they also need relatively long periods of times for species dispersal and establishment.
\end{abstract}


Keywords: Cladonia; terricolous lichens; chronosequence; variation partitioning; old forests; model averaging

\section{Introduction}

In eastern Canadian black spruce (Picea mariana) boreal forests, terricolous lichens belonging to the genus Cladonia tend to be progressively replaced by feather mosses as time since the last stand replacing fire increases [1-3]. This gradual replacement is associated with the formation and closure of the dominant canopy, which leads to decreased light levels reaching the ground and increased humidity in the understory, conditions that are more favorable for mosses [4-6].

However, even if terricolous lichen cover tends to decrease in older stands, these stands are also likely to contain species that are specifically described as late-successional [7-9]. The later appearance of these species could be due to limitations in terms of dispersal or colonization capabilities [10-13] or to their association with micro-habitats that are only present in older forest, such as shaded coarse woody debris $[7,9,14,15]$.

In western Quebec, post-fire succession is generally characterized by the progressive replacement of young, relatively dense even-aged black spruce stands with more open stands with irregular structure, mostly dominated by the same tree species after a period of $c a$. 100-150 years [16]. The presence of a flat topography, poorly drained clay soils, and a relatively cold climate also favor an accumulation of organic matter with time (process of paludification [6,17]). As a result of this process, old forests $(>200$ years) are often paludified and relatively unproductive compared with younger stands because the organic layer is a poor substrate for tree growth compared with mineral soil [17]. These relatively unproductive uneven-aged forests are known to host a particularly rich liverwort flora [18] and a high abundance of epiphytic lichens [19], but their suitability for terricolous lichens is still poorly investigated.

Many studies have been undertaken on terricolous lichen communities in Canadian boreal forests (e.g. $[1,20,21])$. However, few examined the relative contribution of the time elapsed since the last fire (time for species colonization and growth) and microhabitat quality and/or availability in shaping lichen communities. This question is important for determining the proper forest management strategies to maintain species diversity and abundance of terricolous lichen communities. For instance, if some lichen species are restricted to old forests primarily because they need a long period of time to establish and grow in the location, it will be necessary to emphasize a landscape management approach where forest patches containing source populations are maintained at all times in the forest mosaic. Alternatively, if terricolous lichen communities are mainly restricted to old forests because of microhabitat requirements, then a stand-scale approach where forest practices mimic or maintain these specific microhabitats could be successful. Improving our understanding of factors controlling lichen abundance in this ecosystem may also contribute to the preservation of the forest-dwelling ecotype of woodland caribou (Rangifer tarundus caribou), an endangered subspecies that relies mainly on terricolous lichens, particularly during winter [22,23]. 
In this study, we document the structure and composition of terricolous lichen communities along a post-fire chronosequence (43 to 355 years old) in black spruce forests of western Quebec. We address two questions: (1) do species composition, richness, and abundance vary according to time since the last fire? and (2) is it time for colonization and growth or specific microhabitats that are the most important in explaining lichen composition, abundance, and richness?

\section{Materials and Methods}

\subsection{Study Area}

The study was undertaken in the northwestern part of the Abitibi region of Quebec $\left(\left(49^{\circ} 03^{\prime}-49^{\circ} 05^{\prime} \mathrm{N}\right.\right.$, $\left.75^{\circ} 50^{\prime}-79^{\circ} 09^{\prime} \mathrm{W}\right)$. This region is part of the northern Clay Belt, a broad physiographic unit characterized by lacustrine deposits from the proglacial lakes Barlow and Ojibway [24]. The topography is relatively flat, and the forest mosaic is dominated by mono-specific black spruce (Picea mariana) stands [25]. Jack pine (Pinus banksiana) stands are also found in the region, but are limited to drier sites such as outwash deposits, old beaches, and eskers [25], which were not investigated in this study. In the southern part of the study area (weather station located at La Sarre) and in the northern part of the study area (weather station located at Matagami), mean annual temperature (1971-2000) is 0.7 and $-0.7{ }^{\circ} \mathrm{C}$, respectively; total mean annual precipitation (1971-2000) is 890 and $906 \mathrm{~mm}$, respectively; and mean annual snow precipitation is 247 and $314 \mathrm{~cm}$, respectively [26]. Forest fires are a major driver of forest and ecosystem dynamics in this region: the pre-industrial fire return interval has been estimated to be 400 years by Bergeron et al. [27].

\subsection{Sampling}

We sampled terricolous lichens in stands representative of the pristine black spruce forest mosaic that were never logged in the past and varied with respect to time since the last fire. For relatively young stands ( $<100$ years old), stand age (fire year) was determined from a stand initiation map [27] and validated by counting rings from cross sections of dominant trees. In older stands, stand age was determined by crossdating cross-sections of dominant dead and live trees [28]. Radiocarbon dating of carbonized plant remains was also used in stands older than 200 years to date the fire year (more details on stand age determination are given in Lecomte et al. [28]. Sampled stands were all located on clay deposits, and in situ analyses of the forest floor, topography, soil texture, and fire severity were performed to insure that initial conditions were similar for all stands (for more details on site selection, see Lecomte et al. [29]). Selected stands were dominated by black spruce, had to be $>2$ ha to avoid edge effects, and had to be located $>30 \mathrm{~m}$ from the road. All selected sites originated from a high severity fire (low severity fires can lead to a different successional pathway than high severity fires; see Lecomte et al. [29]).

Overall, 12 stands distributed across five age classes were selected for this study. There were two sites in the 50-year age class (range 43-50 years), three sites in the 90-year age class (range 87-93 years), two sites in the 130-year age-class (range 126-130), three sites in the 180-year age class (range 176-180 years), and two sites in the $>280$-year age class (range 280-355 years). In each site, we used three plots of $100 \mathrm{~m}^{2}$ to study terricolous lichens. The first plot was located at least $30 \mathrm{~m}$ from the road and the two other plots were located randomly with a minimal distance of $50 \mathrm{~m}$ from each other. Within each plot, 
10 microplots of $1 \mathrm{~m}^{2}$ were randomly located. In each microplot, we estimated the percent cover of each Cladonia species and the percent cover of all lichen species combined, all bryophyte species combined, and the cover of vascular plants. In the center of each microplot, organic layer depth and canopy cover (quantified with a densitometer) were measured. Within a radius of $3 \mathrm{~m}$ from the center of each microplot, the diameter at breast-height (DBH) of all trees $>5 \mathrm{~cm}$ (live or dead) was measured to calculate basal area. We also counted coarse woody debris $(\mathrm{CWD})>5 \mathrm{~cm}$ diameter at the base.

\subsection{Data Analyses}

\subsubsection{Stand Characteristics}

Nested ANOVAs were used to find differences between age classes for environmental variables. Age class was a fixed factor and microplot was a random factor nested within the interaction of sampling site and age class. Nested ANOVAs were performed on ranks of the variables because they did not follow the assumptions of parametric ANOVAs.

\subsubsection{Cover and Richness Values}

We assessed the influence of environmental variables with regression models, by using plot-level lichen cover and lichen richness as dependent variables. We used the Akaike information criterion corrected for small sample size (AICc) [30] to compare statistical models constituting different combinations of environmental variables. We used model averaging [31] on the entire set of models. Models tested in the model selection analyses are presented in Table 1. Each model represented a biological hypothesis to evaluate the importance of time since fire, canopy cover, and ground characteristics in explaining the species richness and abundance. Because we expected that the richness and/or the abundance of lichens might be more important at the beginning and at the end of the succession gradient, we also added a quadratic term for the age of the stand in some models. Ground variables were represented by CWD density, organic layer depth, moss cover, and plant cover. Analyses were conducted with the AICcmodavf package [32]. Multicollinearity between the environmental variables was assessed using variance inflation factors (VIF). To facilitate assessment of their relative contribution in the models, all variables were standardized before the statistical analyses [33].

\subsubsection{Species Composition}

We used correspondence analysis to explore the relations between environmental variables and community structure. Analyses were performed at the plot level (mean values from the 10 microplots) on abundance data. The analyses were carried out with the CCA function of the vegan package [34]. All species were included in the ordination. A posteriori, we performed Spearman correlations between plot scores on the ordination axes and environmental variables (basal area, canopy cover, CWD density, organic layer depth, moss cover, and plant cover).

We identified indicator species for the age classes with the method of Dufrêne and Legendre [35] in the PC-ORD software version 4.34 [36]. Analyses were performed at the plot level (mean values from the 10 microplots). The indicator values were calculated using the relative abundance and percent cover of species for each plot. Indicator values fell between 0 and 100, where 100 was given to a species found 
exclusively in all plots of a single site-index class. Significance of these indicator values was assessed by Monte Carlo tests (1000 permutations).

Compositional differences between the age classes were tested by a multi-response permutation procedure (MRPP) [36] using the Sorensen distance measure and rank transformation of the distance matrices. Multiple pair-wise comparisons were performed to test compositional differences between age classes.

To quantify the variation of the response data explained by a subset of explanatory variables when controlling for other subsets of explanatory variables, we used RDA as proposed by Borcard et al. [37] as a procedure of variation partitioning. Variation partitioning of the response data was undertaken at the plot scale $(n=36)$. Three subsets of environmental variables were created: stand age, canopy cover, and ground variables. In the subset age, age of the stand and its quadratic term were considered. Ground variables included CWD density, organic layer depth, moss cover, and plant cover. The analyses were conducted with the function varpart in the vegan package [34].

Table 1. Candidate models used to relate lichen richness and lichen cover to age, canopy cover, and ground variables. Age variables included stand age and the quadratic term of the age of the stand. Ground variables included coarse woody debris density, moss cover, plant cover, and organic layer depth.

\begin{tabular}{c}
\hline Candidate Models \\
\hline Age + Canopy cover + Ground \\
Age + Ground \\
Age + Canopy cover \\
Canopy cover + Ground \\
Age \\
Canopy cover \\
Ground \\
Coarse woody debris density \\
Moss cover \\
Plant cover \\
Organic layer depth \\
Intercept only
\end{tabular}

\section{Results}

A total of 39 species were found in this study, 33 belonging to the genus Cladonia, three to the genus Peltigera, and three to the genus Cetraria (Table A1). Cladonia rangiferina, C. stellaris, and C. mitis were the most common species. These three species accounted for $82 \%, 30 \%, 33 \%, 72 \%$, and $90 \%$ of the lichen cover of the $50,90,130,180$, and $>280$ year age classes, respectively.

\subsection{Stand Characteristics}

Organic layer depth was significantly higher in stands older than 180 years compared to stands younger than 90 years (Table 2). Similarly, stands of the two older classes (180 and $>280$ years old) had a forest canopy that was significantly more open than the two younger classes (50 and 90 years old). Stands from 90 years old showed the highest basal area but the difference was significant only from stands 
between 180 years and $>280$ years old. CWD debris density was highest in the 180 -year-old stands. Stand age was positively correlated with organic layer depth ( $\left.r_{\text {Spearman }}=0.674, p<0.001\right)$, and negatively correlated with basal area ( $\left.r_{\text {Spearman }}=0.556, p<0.001\right)$ and moss cover $\left(r_{\text {Spearman }}=-0.453\right.$, $p=0.006)$. Basal area decreased with an increase of organic layer depth $($ rspearman $=-0.704, p<0.001)$. CWD density and moss cover showed a significant negative correlation ( rspearman $=-0.358, p=0.032)$. Plant cover was not significantly correlated with any variables.

Table 2. Mean ( \pm SD) of environmental variables for each age class and number of microplots in each age class $(n)$; ANOVAs were used to compare means between different age classes; means with different letters differed significantly $(p \leq 0.05)$ according to LSmeans Tukey HSD tests.

\begin{tabular}{|c|c|c|c|c|c|c|c|c|c|c|c|c|}
\hline \multirow[b]{2}{*}{ Variable } & \multicolumn{2}{|c|}{50 Years } & \multicolumn{2}{|c|}{90 Years } & \multicolumn{2}{|c|}{130 Years } & \multicolumn{2}{|c|}{180 Years } & \multicolumn{2}{|c|}{$>280$ Years } & \multirow[b]{2}{*}{$F$} & \multirow[b]{2}{*}{$p$} \\
\hline & $n$ & $\begin{array}{c}\text { Mean } \pm \\
\text { SD }\end{array}$ & $n$ & $\begin{array}{c}\text { Mean } \pm \\
\text { SD }\end{array}$ & $n$ & $\begin{array}{c}\text { Mean } \pm \\
\text { SD }\end{array}$ & $n$ & $\begin{array}{c}\text { Mean } \\
\pm \text { SD }\end{array}$ & $n$ & $\begin{array}{c}\text { Mean } \pm \\
\text { SD }\end{array}$ & & \\
\hline $\begin{array}{c}\text { Organic } \\
\text { layer depth }\end{array}$ & $\begin{array}{l}6 \\
0 \\
\end{array}$ & $\begin{array}{c}22.9 \pm \\
7.2 b \\
\end{array}$ & 90 & $\begin{array}{c}25.3 \pm \\
10.6 b \\
\end{array}$ & 60 & $\begin{array}{l}34.6 \pm \\
10.5 \mathrm{ab} \\
\end{array}$ & 90 & $\begin{array}{c}35.7 \pm \\
7.2 \mathrm{a} \\
\end{array}$ & $\begin{array}{l}6 \\
0 \\
\end{array}$ & $\begin{array}{c}41.3 \pm \\
8.9 \mathrm{a} \\
\end{array}$ & 7.11 & $<0.001$ \\
\hline Canopy cover & $\begin{array}{l}6 \\
0 \\
\end{array}$ & $\begin{array}{l}76.7 \pm \\
14.7 \mathrm{a} \\
\end{array}$ & 90 & $\begin{array}{l}71.9 \pm \\
21.7 \mathrm{a} \\
\end{array}$ & 60 & $\begin{array}{l}60.0 \pm \\
26.9 \mathrm{ab}\end{array}$ & 90 & $\begin{array}{l}41.5 \pm \\
18.6 \mathrm{~b} \\
\end{array}$ & $\begin{array}{l}6 \\
0 \\
\end{array}$ & $\begin{array}{c}43.3 \pm \\
19.5 b\end{array}$ & 9.04 & $<0.001$ \\
\hline Basal area & $\begin{array}{l}6 \\
0 \\
\end{array}$ & $\begin{array}{l}26.0 \pm \\
18.6 \mathrm{ab}\end{array}$ & 90 & $\begin{array}{l}33.6 \pm \\
21.3 \mathrm{a} \\
\end{array}$ & 60 & $\begin{array}{l}23.6 \pm \\
16.6 \mathrm{ab}\end{array}$ & 90 & $\begin{array}{l}21.0 \pm \\
17.7 \mathrm{~b}\end{array}$ & $\begin{array}{l}6 \\
0 \\
\end{array}$ & $\begin{array}{l}14.5 \pm \\
12.8 \mathrm{~b} \\
\end{array}$ & 5.41 & 0.002 \\
\hline $\begin{array}{l}\text { Coarse woody } \\
\text { debris density }\end{array}$ & $\begin{array}{l}6 \\
0\end{array}$ & $\begin{array}{l}2.4 \pm \\
2.6 \mathrm{~b}\end{array}$ & 89 & $\begin{array}{l}3.6 \pm \\
3.0 \mathrm{~b}\end{array}$ & 60 & $\begin{array}{l}2.5 \pm \\
2.6 b\end{array}$ & 90 & $\begin{array}{c}6.6 \pm \\
5.2 \mathrm{a}\end{array}$ & $\begin{array}{l}6 \\
0\end{array}$ & $\begin{array}{l}3.6 \pm \\
3.8 \mathrm{ab}\end{array}$ & 4.54 & 0.005 \\
\hline
\end{tabular}

\subsection{Cover and Richness Values}

A significant quadratic relationship $\left(R^{2}=0.71, p<0.0001\right)$ was found between lichen cover and stand age: lichen cover first decreased in sites of ca. 100 years old, and then increased in sites $>200$ years old (Figure 1a). The effect of stand age on lichen richness was not significant (Figure 1b).

Figure 1. Relationships between (a) lichen cover and stand age; and (b) lichen richness and stand age; line is shown only for the significant regression.
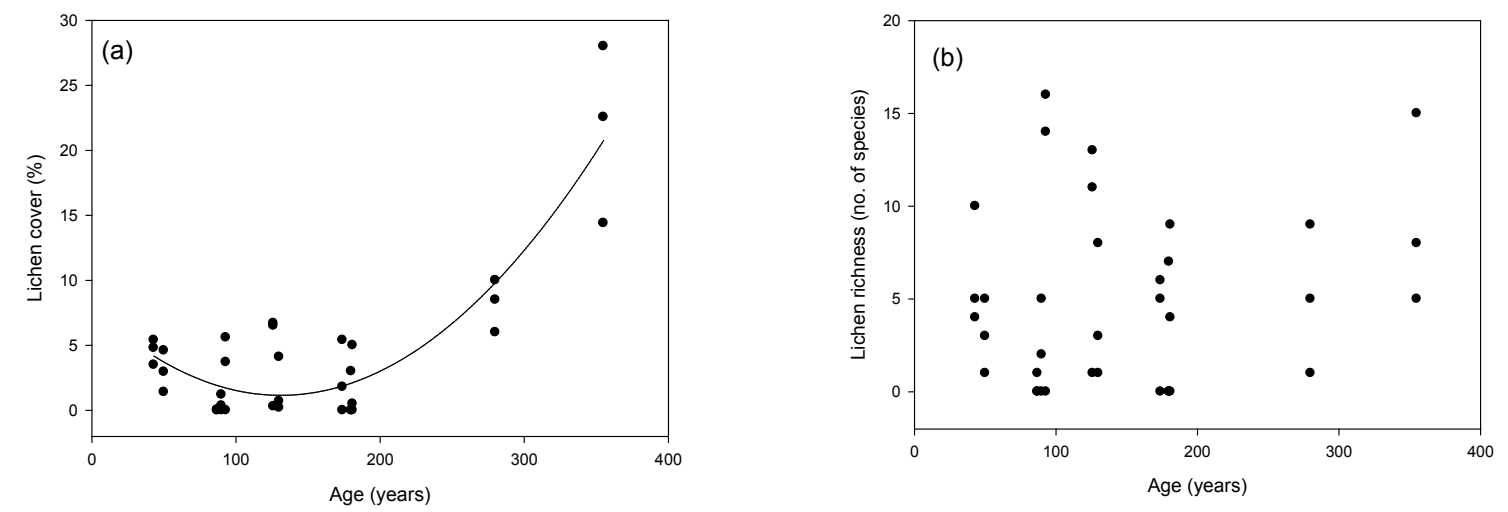
The best model explaining lichen species richness (model including organic matter depth only) was only 1.8 times (i.e. $0.37 / 0.21$ ) more likely than the second best model, which included ground variables only (Table 3). After model averaging, two variables had $95 \%$ confidence intervals that excluded 0 , which respectively had a positive and a negative influence on species richness (Table 4).

Table 3. Model selection results for richness and cover of lichen. Only models for which the sum of AICc weights reached $\geq 0.95$ ) are presented; models are classified using Akaike's information criterion (AICc), including difference in AICc ( $\triangle \mathrm{AICc})$, Akaike weight (w), and the number of parameters included $(\mathrm{K})$.

\begin{tabular}{clccc}
\hline Model & K & AICc & $\Delta$ AICc & W \\
\hline Lichen richness & & & & \\
\hline Organic layer depth & 3 & 213.57 & 0 & 0.37 \\
Ground & 6 & 214.73 & 1.16 & 0.21 \\
CWD & 3 & 215.36 & 1.79 & 0.15 \\
Canopy cover & 3 & 217.21 & 3.64 & 0.06 \\
Intercept only & 2 & 217.29 & 3.72 & 0.06 \\
Canopy cover + ground & 7 & 217.81 & 4.24 & 0.04 \\
Age + Canopy cover & 5 & 218.66 & 5.09 & 0.03 \\
Moss cover & 3 & 219.39 & 5.82 & 0.02 \\
Plant cover & 3 & 219.42 & 5.85 & 0.02 \\
\hline Lichen cover & & & & \\
\hline Age & 4 & 184.09 & 0 & 0.43 \\
Age + Canopy cover & 5 & 185.09 & 0.96 & 0.26 \\
Age + Ground & 8 & 185.07 & 0.98 & 0.26 \\
\hline
\end{tabular}

Note: $\mathrm{CWD}=$ coarse woody debris density.

Table 4. Average estimates, unconditional standard errors, and confidence intervals (CI) based on model averaging; $95 \%$ confidence interval of coefficients in bold excluded 0 .

\begin{tabular}{lcccr}
\hline $\begin{array}{c}\text { Dependent } \\
\text { variable }\end{array}$ & Independent variable & Estimate & SE & \multicolumn{1}{c}{$\mathbf{9 5 \%}$ CI } \\
\hline \multirow{4}{*}{ Richness } & Age & -1.26 & 1.65 & $(-4.45,1.94)$ \\
& Age & 1.66 & 1.26 & $(-0.82,4.14)$ \\
& Canopy cover & -0.91 & 1.28 & $(-3.41,1.60)$ \\
& Organic layer depth & 1.87 & 0.80 & $(\mathbf{0 . 3 1}, \mathbf{3 . 4 3})$ \\
& Coarse woody debris density & -1.73 & 0.79 & $(-\mathbf{3 . 2 7}, \mathbf{- 0 . 1 9})$ \\
& Moss cover & -0.96 & 0.80 & $(-2.52,0.60)$ \\
Cover & Plant cover & -0.16 & 0.76 & $(-1.65,1.32)$ \\
& Intercept & 4.92 & 0.74 & $(\mathbf{3 . 4 7}, \mathbf{6 . 3 6})$ \\
\hline & Age & 0.64 & 1.03 & $(-1.38,2.67)$ \\
& Age & 4.76 & 0.75 & $(\mathbf{3 . 2 9}, \mathbf{6 . 2 2})$ \\
& Canopy cover & -0.69 & 0.80 & $(-2.23,0.88)$ \\
& Organic layer depth & 1.73 & 0.70 & $(\mathbf{0 . 3 5}, \mathbf{3 . 1 1})$ \\
& Coarse woody debris density & -0.41 & 059 & $(-1.56,0.75)$ \\
& Moss cover & -0.77 & 0.56 & $(-1.86,0.32)$ \\
& Plant cover & -0.22 & 0.49 & $(-1.17,0.74)$ \\
& Intercept & 4.37 & 0.46 & $(\mathbf{3 . 5 6 , 5 . 2 8})$ \\
\hline
\end{tabular}


The model that included age variables (Akaike weight of 0.43 ) was the best for explaining lichen cover (Table 3). However, this model was only 1.7 times (i.e. $0.43 / 0.26$ ) more likely to explain lichen cover than the second best model that included age and ground variables (Table 3). After model averaging, only two variables had $95 \%$ confidence intervals that did not include 0 , age ${ }^{2}$, and organic layer depth, which both had positive influence on lichen cover (Table 4). Lichen cover increased with stand age ${ }^{2}$ and organic layer depth (Table 4). $R^{2}$ of the models with average estimates explaining lichen richness and lichen cover were $27.0 \%$ and $80.0 \%$, respectively.

\subsection{Species Composition}

The first two axes of the ordination explained $40 \%$ of the variation in the terricolous lichen community (Axis $1=29 \%$ and Axis $2=11 \%$; Figure 2). Lichen species composition differed between age classes according to MRPP analyses (Table 5). Sites from the $>280$-year age class and the 50 -year age class differed significantly from other age classes. Axis 1 was positively correlated with canopy cover $\left(r_{\text {Spearman }}=0.390, p=0.020\right)$ and moss cover $\left(r_{\text {Spearman }}=0.423, p=0.011\right)$, and negatively correlated with coarse woody debris density $\left(r_{\text {Spearman }}=-0.522, p=0.001\right)$ and organic layer depth $\left(r_{\text {Spearman }}=-0.350\right.$, $p=0.05)$. No significant correlation was found between environmental variables and Axis 2. Plots characterized by a relatively closed canopy and a higher basal area are located in the right-hand part of the ordination plot (Figure 2). Most of these sites belong to the intermediate age classes (90 and 130 years old). Closed-canopy lichen species that usually grow on moss characterized these sites: Cladonia acuminata, Flavocetraria cucullata, Cetraria islandica, F. nivallis, and Peltigera species. Plots with an open canopy structure, a deep layer of organic matter, and plots that mostly belong to the older age classes ( $>180$ years old) were located in the left-hand part of the ordination; lichen species with a preference for open sites such as Cladonia rangiferina, C. cenotea, and C. stellaris were generally more abundant in these plots.

Table 5. Multi-response permutation procedures (MRPP) testing for compositional differences between age classes; $A$ is the chance-corrected within-group agreement $(A=1$ when all items are identical within groups). Bold values are significant at $p \leq 0.05$.

\begin{tabular}{ccccccccc}
\hline \multirow{2}{*}{ Age class } & \multicolumn{2}{c}{$\mathbf{9 0}$ Years } & \multicolumn{2}{c}{$\mathbf{1 3 0}$ Years } & \multicolumn{2}{c}{ 180 Years } & \multicolumn{2}{c}{$>280$ Years } \\
\cline { 2 - 9 } & $\boldsymbol{A}$ & $\boldsymbol{p}$ & $\boldsymbol{A}$ & $\boldsymbol{p}$ & $\boldsymbol{A}$ & $\boldsymbol{p}$ & $\boldsymbol{A}$ & $\boldsymbol{P}$ \\
\hline 50 years & 0.206 & $\mathbf{0 . 0 1 0}$ & 0.162 & $\mathbf{0 . 0 0 7}$ & 0.112 & $\mathbf{0 . 0 5 0}$ & 0.263 & $\mathbf{0 . 0 0 7}$ \\
90 years & - & - & 0.054 & 0.146 & 0.045 & 0.160 & 0.316 & $\mathbf{0 . 0 0 1}$ \\
130 years & - & - & - & - & 0.140 & $\mathbf{0 . 0 3 3}$ & 0.254 & $<\mathbf{0 . 0 0 1}$ \\
180 years & - & - & - & - & - & - & 0.195 & $\mathbf{0 . 0 1 2}$ \\
\hline
\end{tabular}

Cladonia arbuscula had an importance value that was significantly higher in forests of the 50-year age class (Table A1). Indicator species of the older age class ( $>280$ years old) were Cladonia pleurota, and C. stellaris. F. cuculata, C. islandica, and F. nivallis each had a maximal importance value in forests of the 130-year age class.

Stand age alone explained $43.20 \%$ of the variance in the lichen community when controlling for the effect of ground variables and canopy cover according to the RDA analysis (Figure 3). Variation explained by the ground variables and canopy cover when controlling for other subsets were $0.4 \%$ and 
$0 \%$, respectively. Age of the stand and ground variables and age of the stand and canopy cover shared $21.7 \%$ and $5.5 \%$ of the variance, respectively. The variance shared between the ground variables and canopy cover was $6.1 \%$.

Figure 2. Correspondence analysis showing (a) the position of plots according to their species composition; (b) the position of terricolous lichens; and (c) vector plot showing the relationships between the environmental variables (CWD = coarse woody debris density) and the ordination axes. Only species present in more than three plots are presented. Species codes are as follow: CISL, Cetraria islandica; CACU, Cladonia acuminata; CBAC, Cladonia bacilliformis; CBEL, Cladonia bellidiflora; CBOR, Cladonia borealis; CCEN, Cladonia cenotea; CCHL, Cladonia chlorophaea; CMIT, Cladonia mitis; CMUL, Cladonia multiformis; CRAM, Cladonia ramulosa; CRAN, Cladonia rangiferina; CLAST, Cladonia stellaris; FCUC, Flavocetraria cucullata; FNIV, Flavocetraria nivalis; PRUF, Peltigera rufescens; PAPH, Peltigera aphtosa; and PSCA, Peltigera scabrosa.

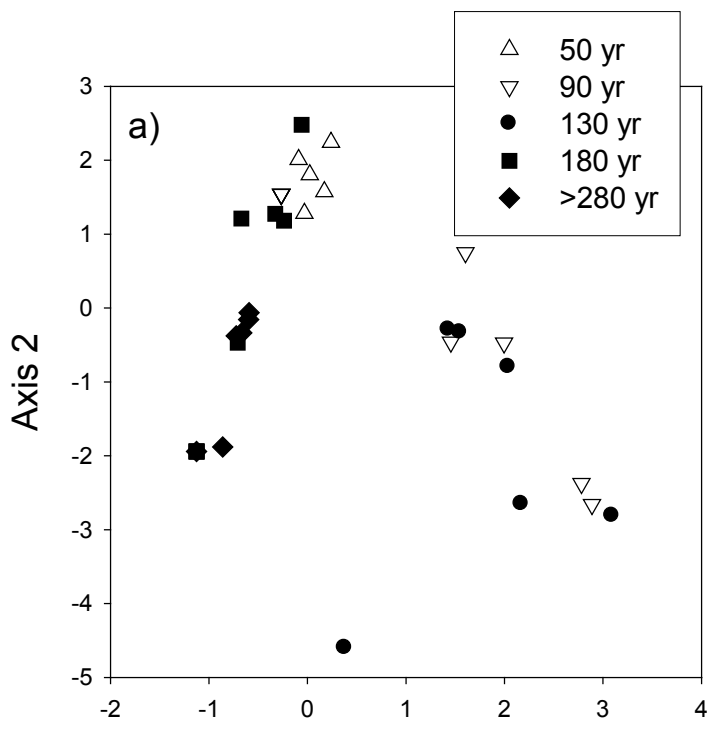

Axis 1

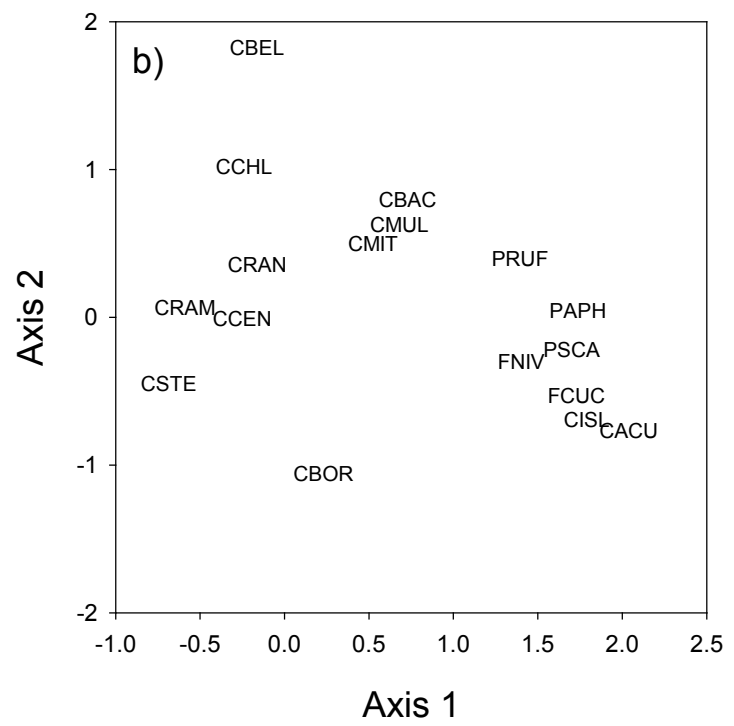

Axis 1

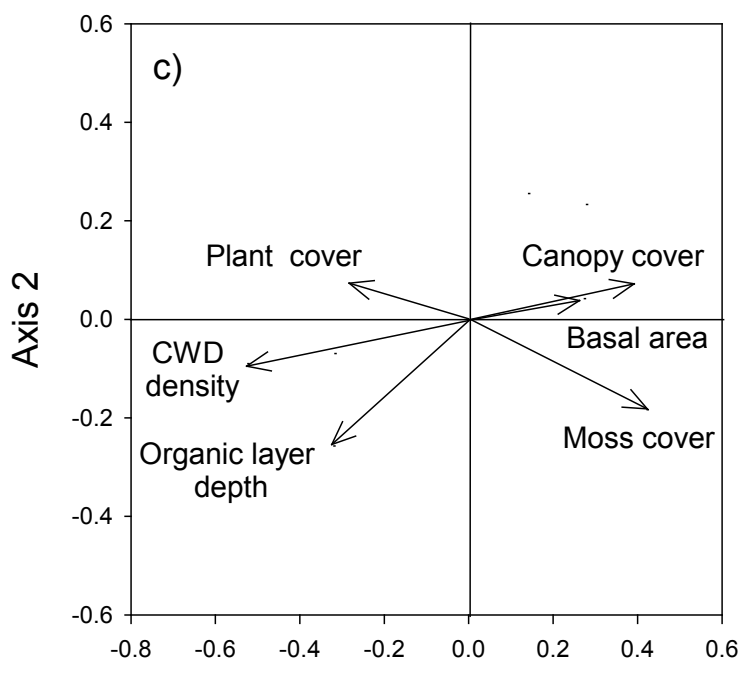

Axis 1 
Figure 3. Variation partitioning of the terricolous lichen abundance data at the plot scale $\left(100 \mathrm{~m}^{2}\right)$ between $(\mathbf{A})$ age of the stand; $(\mathbf{B})$ ground variables; and $(\mathbf{C})$ canopy cover.

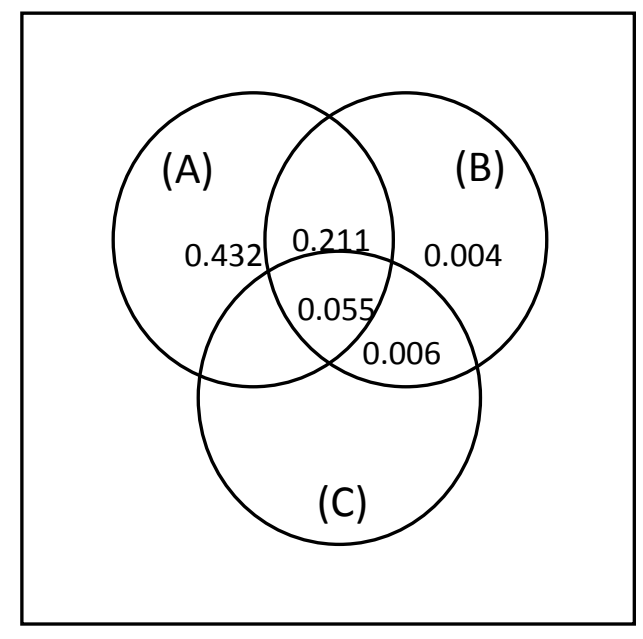

Values $<0$ not shown

\section{Discussion}

This study addresses a fundamental question for forest ecosystem management: is it stand age or stand characteristics that have the most influence on lichen species composition and abundance? Our results indicate that the time elapsed since the last fire was the factor that contributed the most to explaining terricolous lichen abundance and species composition. To our knowledge, this question has not been addressed before for terricolous lichens. Differences in composition arise principally from large foliose species (e.g. Flavocetraria cuculata, C. islandica, and F. nivellis) that typified forests from the 90- and 130-year age classes, and from high cover of caribou lichens associated with the youngest (Cladonia arbuscula and C. mitis) and oldest (C. rangiferina and C. stellaris)age classes.

Even if the limiting effect of lichen dispersal cannot be evaluated directly in this study because distance from the closest fire escapes were not evaluated, it is likely that the mode of dispersal of different species groups explains some part of the variations in species composition between age classes. For most Cladonia species, dispersal strategy is either by soredia, small vegetative propagules that contain the mycobiont and the photobiont, or by spores [38]. These modes of dispersal are considered efficient modes for lichen species dispersal [39-41]. The main dispersal strategy for species belonging to the Cladina group (Cladonia mitis, C. rangiferina, C. stellaris) has been suggested to be through thallus fragments [42-45], which have a higher rate of successful establishment but a lower dispersal capability than other diaspores $[42,46]$. Heinken [47] studied the dispersal of thallus fragments of seven terricolous lichen species and found the distance of dispersal was shorter than one meter by wind and about $10 \mathrm{~m}$ by animal dispersal. It is likely that the time elapsed since the last fire had a positive effect on Cladina colonization by increasing the probability that large thallus fragments successfully reach the sites, particularly in the case of $C$. stellaris and C. rangiferina, which are particularly abundant in older ( $>280$ years) forests.

In a general manner, lichen development rates have been considered to be relatively slow, and many years can elapse before the appearance of a mature thallus [48] and the production of propagules $[49,50]$. Environmental factors such as snow accumulation on the diaspores can also have an 
effect through the reduction of the growing season for terricolous lichens [48]. Overall, it can be reasonably expected that time since the last disturbance will have a positive effect on the probability of lichen establishment and growth in a site. The association between C. stellaris and late successional forests [51,52] has previously been explained by the low growth rate of this species compared with the other caribou lichen species studied [53]. However, as den Herder et al. [54] found in Finland, higher growth rates for $C$ stellaris compared with $C$. mitis and $C$. rangiferina were previously found in our study area, including in dense forest stands where the abundance of $C$. stellaris is naturally relatively low [55]. Thus, it is unlikely that the association between $C$. stellaris and older forests in this study can be attributed to a lower growth rate for this species. An important effect of time since last disturbance, distinct from microhabitat availability, has also been suggested for other organisms potentially limited by dispersal in boreal forests such as liverworts [18,56,57] and epiphytic lichens [10,19]. However, the exact biological mechanism underlying these statistical relationships remains poorly documented at the moment due to a poor documentation of traits associated with dispersal for these organisms [58].

Despite the overall importance of stand age, the presence of suitable micro-habitats was an important prerequisite for some species. Thickness of the organic layer was important for overall lichen cover, species composition, and species richness. The establishment and growth of terricolous lichens may be favored by the accumulation of the organic layer and the increase in moss cover [23] because these substrates increase the length of hydration periods [59,60]. The increase in organic matter depth may favor the abundance of Cladonia stellaris over the other mat-forming species. Indeed, Kershaw and Rouse [61] found that $C$. stellaris metabolizes at a higher water saturation level than C. rangiferina, and this latter is thus associated with dryer microsites than C. stellaris [62].

In this study, stand structural variables played a minor role for lichen abundance and species richness. Structural variables have been considered to influence lichen growth and were considered important in explaining the composition of terricolous lichen communities in many studies [5,43,46,51]. For example, Sulyma and Coxson [63] have proposed that a decrease in ventilation in forest stands where canopy leaf area index is high (dense stands) can have the effect of increasing air humidity and favoring the establishment of feather mosses at the expense of lichens. Despite the weak relationships that we observed, it is possible that terricolous lichens were favored by the more diverse light conditions, lower humidity levels, and greater ventilation present in stands older than 180 years.

Finally, it is important to emphasize that this study took place on clay soils, which is the most representative site type in the region [29]. Terricolous lichens are known to exhibit different community structures on different types of surficial deposits [64], and thus the relationships with forest continuity could be different on soil types with coarser or finer textures, something that should be investigated by future studies.

\section{Conclusions}

This study indicates that time elapsed since the last disturbance is a significant driver for terricolous lichen communities. Forest management strategies that facilitate lichen demographic processes requiring long periods of time, such as propagule dispersal and establishment, could be important in this context. The maintenance of relatively undisturbed forest habitat patches that contain source populations and are well distributed in managed forest mosaics, could facilitate a successful recolonization of disturbed 
habitats in future landscapes [12]. However, the formulation of more precise guidelines for the retention of terricolous lichen assemblages typical of old forest habitats would greatly benefit from a better knowledge of the dispersal, colonization, and growth capabilities of individual species [58].

\section{Acknowledgments}

We are grateful to Élise Marquis for her help in the field, and to Nicolas Lecomte and Nicole Fenton for their help with site selection. Funding was provided by the Fonds Forestier-Action concertee research program of the Fonds québécois de la recherche sur la nature et les technologies (FQRNT), the Sustainable Forest Management Network, the Groupe de recherche en écologie forestière interuniversitaire (UQAM), and the Natural Sciences and Engineering Research Council UQAM-UQAT industrial chair in sustainable forest management.

\section{Author Contributions}

The paper was written by Catherine Boudreault and Saliha Zouaoui, with contribution from Pierre Drapeau and Yves Bergeron. Saliha Zouaoui was responsible for the sampling design, with contribution from Pierre Drapeau and Yves Bergeron. Saliha Zouaoui did all the field and laboratory work, including species identifications. Catherine Boudreault was responsible for the statistical analyses, with equal support from all the other co-authors.

\section{Conflicts of Interest}

The authors declare no conflict of interest.

\section{Appendix}

Table A1. Mean cover of species (\%) and number of microplots $(n)$ where species were present in the different age classes; * is for indicator species of an age class.

\begin{tabular}{|c|c|c|c|c|c|c|c|c|c|c|}
\hline \multirow[t]{2}{*}{ Species } & \multicolumn{2}{|c|}{50 Years } & \multicolumn{2}{|c|}{90 Years } & \multicolumn{2}{|c|}{130 Years } & \multicolumn{2}{|c|}{180 Years } & \multicolumn{2}{|c|}{$\begin{array}{c}>280 \\
\text { Years }\end{array}$} \\
\hline & $n$ & $\%$ & $n$ & $\%$ & $n$ & $\%$ & $n$ & $\%$ & $N$ & $\%$ \\
\hline Cetraria islandica & 0 & 0 & 6 & 0.1 & $9 *$ & 0.35 & 0 & 0 & 0 & 0 \\
\hline Cladonia acuminata & 0 & 0 & 3 & 0.03 & 2 & 0.05 & 0 & 0 & 0 & 0 \\
\hline Cladonia arbuscula & $9 *$ & 0.43 & 0 & 0 & 0 & 0 & 0 & 0 & 0 & 0 \\
\hline Cladonia bellidiflora & 2 & 0.03 & 0 & 0 & 0 & 0 & 3 & 0.03 & 0 & 0 \\
\hline Cladonia bacilliformis & 1 & 0.02 & 0 & 0 & 1 & 0.02 & 1 & 0.01 & 0 & 0 \\
\hline Cladonia borealis & 0 & 0 & 0 & 0 & 3 & 0.05 & 2 & 0.02 & 2 & 0.05 \\
\hline Cladonia botrytes & 0 & 0 & 0 & 0 & 0 & 0 & 2 & 0.03 & 2 & 0.03 \\
\hline Cladonia caespiticia & 1 & 0.02 & 1 & 0.01 & 0 & 0 & 0 & 0 & 0 & 0 \\
\hline Cladonia cariosa & 0 & 0 & 2 & 0.02 & 0 & 0 & 0 & 0 & 0 & 0 \\
\hline Cladonia carneola & 1 & 0.02 & 1 & 0.02 & 1 & 0.02 & 0 & 0 & 0 & 0 \\
\hline Cladonia cenotea & 1 & 0.03 & 0 & 0 & 1 & 0.03 & 1 & 0.01 & 1 & 0.13 \\
\hline Cladonia chlorophaea & 3 & 0.08 & 1 & 0.01 & 0 & 0 & 4 & 0.11 & 5 & 0.15 \\
\hline Cladonia coniocraea & 0 & 0 & 1 & 0.02 & 0 & 0 & 0 & 0 & 0 & 0 \\
\hline
\end{tabular}


Table A1. Cont.

\begin{tabular}{|c|c|c|c|c|c|c|c|c|c|c|}
\hline \multirow[t]{2}{*}{ Species } & \multicolumn{2}{|c|}{50 Years } & \multicolumn{2}{|c|}{90 Years } & \multicolumn{2}{|c|}{130 Years } & \multicolumn{2}{|c|}{180 Years } & \multicolumn{2}{|c|}{$\begin{array}{l}>280 \\
\text { Years }\end{array}$} \\
\hline & $n$ & $\%$ & $n$ & $\%$ & $n$ & $\%$ & $n$ & $\%$ & $N$ & $\%$ \\
\hline Cladonia cornuta ssp. cornuta & 0 & 0 & 1 & 0.02 & 2 & 0.05 & 2 & 0.03 & 1 & 0.02 \\
\hline Cladonia cristatella & 0 & 0 & 0 & 0 & 0 & 0 & 0 & 0 & 2 & 0.03 \\
\hline Cladonia cyanipes & 0 & 0 & 0 & 0 & 0 & 0 & 0 & 0 & 1 & 0.11 \\
\hline Cladonia digitata & 0 & 0 & 0 & 0 & 0 & 0 & 1 & 0.01 & 1 & 0.02 \\
\hline Cladonia ecmocyna & 0 & 0 & 1 & 0.01 & 0 & 0 & 0 & 0 & 1 & 0.02 \\
\hline Cladonia fimbriata & 0 & 0 & 0 & 0 & 0 & 0 & 0 & 0 & 1 & 0.05 \\
\hline Cladonia gracilis ssp. turbinata & 1 & 0.02 & 0 & 0 & 0 & 0 & 1 & 0.13 & 0 & 0 \\
\hline Cladonia macilenta & 3 & 0.05 & 0 & 0 & 2 & 0.03 & 0 & 0 & 0 & 0 \\
\hline Cladonia mitis & 5 & 0.22 & 4 & 0.1 & 2 & 0.25 & 2 & 0.08 & 1 & 0.22 \\
\hline Cladonia multiformis & 0 & 0 & 2 & 0.02 & 0 & 0 & 1 & 0.01 & 1 & 0.02 \\
\hline Cladonia ochrochlora & 1 & 0.03 & 0 & 0 & 0 & 0 & 0 & 0 & 0 & 0 \\
\hline Cladonia phyllophora & 1 & 0.01 & 1 & 0.01 & 0 & 0 & 0 & 0 & 1 & 0.01 \\
\hline Cladonia pleurota & 0 & 0 & 0 & 0 & 0 & 0 & 0 & 0 & $3 *$ & 0.08 \\
\hline Cladonia ramulosa & 0 & 0 & 0 & 0 & 0 & 0 & 2 & 0.02 & 3 & 0.07 \\
\hline Cladonia rangiferina & 12 & 1.05 & 7 & 0.26 & 6 & 0.63 & 10 & 0.84 & 13 & 3.7 \\
\hline Cladonia rei & 0 & 0 & 1 & 0.01 & 0 & 0 & 1 & 0.01 & 0 & 0 \\
\hline Cladonia scabriuscula & 0 & 0 & 1 & 0.02 & 4 & 0.05 & 0 & 0 & 0 & 0 \\
\hline Cladonia stellaris & 0 & 0 & 0 & 0 & 0 & 0 & 7 & 0.26 & $21 *$ & 5.3 \\
\hline Cladonia squamosa & 0 & 0 & 0 & 0 & 2 & 0.03 & 0 & 0 & 3 & 0.12 \\
\hline Cladonia sulphurina & 0 & 0 & 0 & 0 & 2 & 0.07 & 0 & 0 & 3 & 0.1 \\
\hline Cladonia uncialis & 0 & 0 & 0 & 0 & 0 & 0 & 0 & 0 & 1 & 0.02 \\
\hline Flavocetraria cucullata & 0 & 0 & 12 & 0.24 & $13 *$ & 0.53 & 0 & 0 & 1 & 0.02 \\
\hline Flavocetraria nivalis & 3 & 0.07 & 7 & 0.13 & $11 *$ & 0.35 & 0 & 0 & 3 & 0.05 \\
\hline Peltigera aphtosa & 0 & 0 & 4 & 0.09 & 2 & 0.08 & 0 & 0 & 0 & 0 \\
\hline Peltigera rufescens & 0 & 0 & 3 & 0.03 & 1 & 0.02 & 1 & 0.01 & 0 & 0 \\
\hline Peltigera scabrosa & 0 & 0 & 2 & 0.02 & 2 & 0.05 & 0 & 0 & 0 & 0 \\
\hline No. of lichens species & 15 & & 21 & & 18 & & 16 & & 23 & \\
\hline
\end{tabular}

\section{References}

1. Foster, D.R. Vegetation development following fire in Picea mariana (black spruce)-Pleurozium forests of south-eastern Labrador, Canada. J. Ecol. 1985, 73, 517-534.

2. Taylor, S.J.; Carleton, T.J.; Adams, P. Understory vegetation change in a chronosequence. Vegetatio 1987, 73, 63-72.

3. Carleton, T.J.; Maycock, P.J. Vegetation of the boreal forests south of James Bay: Non-centered component analysis of the vascular flora. Ecology 1980, 61, 1199-1212.

4. Esseen, P.A.; Ehnstrôm, B.; Ericson, L.; Sjôberg, K. Boreal forests. Ecol. Bull. 1997, 46, 16-47.

5. Coxson, D.S.; Marsh, J. Lichen chronosequences (postfire and postharvest) in lodgepole pine (Pinus contorta) forest of northern interior British Columbia. Can. J. Bot. 2001, 79, 1449-1464. 
6. Fenton, N.; Lecomte, N.; Légaré, S.; Bergeron, Y. Paludification in black spruce (Picea mariana) forests of eastern Canada: Potential factors and management implications. For. Ecol. Manag. 2005, 213, 151-159.

7. Rheault, H.; Bélanger, L.; Grondin, P.; Ouimet, R.; Hébert, C.; Dussault, C. Stand composition and structure as indicators of epixylic diversity in old-growth boreal forests. Écoscience 2009, 16, 183-196.

8. Desponts, M.; Desrochers, A.; Bélanger, L.; Huot, J. Structure de sapinières aménagées et anciennes du massif des Laurentides (Québec) et diversité des plantes invasculaires. Can. J. For. Res. 2002, 32, 2077-2093.

9. Kruys, N.; Jonsson, B.G. Fine woody debris is important for species richness on logs in managed boreal spruce forests of northern Sweden. Can. J. For. Res. 1999, 29, 1295-1299.

10. Dettki, H.; Esseen, P.A. Modelling long-term effects of forest management on epiphytic lichens in northern Sweden. For. Ecol. Manag. 2003, 175, 223-238.

11. Nordén, B.; Appelqvist, T. Conceptual problems of ecological continuity and its bioindicators. Biodiv. Conserv. 2001, 10, 779-791.

12. Hilmo, O.; Såstad, S. Colonization of old-forest lichens in a young and an old boreal Picea abies forest: An experimental approach. Biol. Conserv. 2001, 102, 251-259.

13. Keon, D.B.; Muir, P. Growth of Usnea longissima across a variety of habitats in the Oregon coast range. Bryologist 2002, 105, 233-242.

14. Lättman, H.; Lindblomc, L.; Mattsson, J.E.; Milberg, P.; Skage, M.; Ekmanc, S. Estimating the dispersal capacity of the rare lichen Cliostomum corrugatum. Biol. Conserv. 2009, 142, 1870-1878.

15. Söderström, L. The occurrence of epixylic bryophyte and lichen species in an old natural and a managed forest stand in Northeast Sweden. Biol. Conserv. 1998, 45, 169-178.

16. Harper, K.A.; Bergeron, Y.; Drapeau, P.; Gauthier, S.; DeGrandpré, L. Structural development following fire in black spruce boreal forest. For. Ecol. Manag. 2005, 206, 293-306.

17. Simard, M.; Lecomte, N.; Bergeron, Y.; Bernier, P.Y.; Paré, D. Forest productivity decline caused by successional paludification of boreal soils. Ecol. Appl. 2007, 17, 1619-1637.

18. Fenton, N.J.; Bergeron, Y. Does time or habitat make old-growth forests species rich? Bryophyte richness in boreal Picea mariana forests. Biol. Conserv. 2008, 141, 1389-1399.

19. Boudreault, C.; Bergeron, Y.; Coxson, D.S. Factors controlling epiphytic lichen biomass accumulation during postfire succession in black spruce boreal forests. Can. J. For. Res. 2009, 39, 2168-2179.

20. Morneau, C.; Payette, S. Postfire lichen-spruce woodland recovery at the limit of the boreal forest in northern Québec. Can. J. Bot. 1989, 60, 2770-2782.

21. Boudreault, C.; Bergeron, Y.; Gauthier, S.; Drapeau, P. Bryophyte and lichen communities in mature to old-growth stands in eastern boreal forests in Canada. Can. J. For. Res. 2002, 32, 1080-1093.

22. Kelsall, J.P. COSEWIC Status Report on the Woodland Caribou Rangifer tarandus caribou in Canada; Committee on the Status of Endangered Wildlife in Canada: Ottawa, ON, Canada, 1984. 
23. Webb, E.T. Survival, persistence, and regeneration of the reindeer lichens, Cladina stellaris, C. rangiferina, and C. mitis following clear-cut logging and forest fire in Northwestern Ontario. Rangifer 1998, 10, 41-47.

24. Vincent, J.S.; Hardy, L. L'évolution et l'extinction des lacs glaciaires Barlow et Ojibway en territoire québécois. Geogr. Phys. Quatern. 1977, 31, 357-372.

25. Rowe, J.S. Forest Regions of Canada; Environment Canada: Ottawa, ON, Canada, 1972.

26. Environment Canada. Canadian Climate Normals or Averages 1971-2000. Available online: http://www.climate.weatheroffice.ec.gc.ca/climate_normals/results_e.html (accessed on 10 October 2014).

27. Bergeron, Y.; Gauthier, S.; Flannigan, M.; Kafka, V. Fire regimes at the transition between mixedwoods and coniferous boreal forests in Northwestern Québec. Ecology 2004, 85, 1916-1932.

28. Lecomte, N.; Simard, M.; Bergeron, Y. Effects of fire severity and initial tree composition on stand structural development in the coniferous boreal forest of northwestern Québec, Canada. Écoscience 2006, 13, 152-163.

29. Lecomte, N.; Simard, M.; Bergeron, Y.; Larouche, A.; Asnong, H.; Richard, P.J.H. Effects of fire severity and initial tree composition on understorey vegetation dynamics in a boreal landscape inferred from chronosequence and paleoecological data. J. Veg. Sci. 2005, 16, 665-674.

30. Burnham, K.P.; Anderson, D.R. Model Selection and Multimodel Inference: A Practical Information-Theoretic Approach, 2nd ed.; Springer: New York, NY, USA, 2002.

31. Burnham, K.P.; Anderson, D.R. Multimodel inference: Understanding AIC and BIC in model selection. Sociol. Methods Res. 2004, 33, 261-304.

32. Mazerolle, M.J. Package AICcmodavg: Model Selection and Multimodel Inference Based on (Q)AIC(c) Ver. 1.24. Available online: cran.r-project.org/web/packages/AICcmodavg/index.htm (accessed on 10 October 2014).

33. Gelman, A. Scaling regression inputs by dividing by two standard deviations. Stat. Med. 2008, 27, 2865-2873.

34. Oksanen, J.; Kindt, R.; Legendre, P.; O’Hara, B.; Simpson, G.L.; Henry, M.; Stevens, H.H.; Wagner, H. Vegan: Community Ecology Package; R Package Version 1.13-1. Available online: http://vegan.r-forge.r-project.org/ (accessed on 10 October 2014).

35. Dufrêne, M.; Legendre, P. Species assemblages and indicator species: The need for a flexible asymmetrical approach. Ecol. Monog. 1997, 67, 345-366.

36. McCune, B.; Mefford, M.J. PC-ORD. In Multivariate Analysis of Ecological Data, Version 4; MjM Software Design: Gleneden Beach, OR, USA, 1999.

37. Borcard, D.; Gillet, F.; Legendre, P. Numerical Ecology with R. Use R! Series; Springer: New York, NY, USA, 2011.

38. Brodo, I.M.; Sharnoff, S.D.; Sharnoff, S. Lichens of North America; Yale University Press: New Haven, CT, USA, 2001.

39. Mistry, J. Corticolous lichens as potential bioindicators of fire history: A study in the cerrado of the Distrito Federal, central Brazil. J. Biogeogr. 1998, 25, 409-441.

40. Hedenås, H.; Ericson, L. Epiphytic macrolichens as conservation indicators: Successional sequence in Populus tremula stands. Biol. Conserv. 2000, 93, 43-53. 
41. Johansson, P.; Wetmore, C.M.; Carlson, D.J.; Reich, P.B.; Göran, T. Habitat preference, growth form, vegetative dispersal and population size of lichens along a wildfire severity gradient. Bryologist 2006, 109, 527-540.

42. Rogers, R.W. Ecological strategies of lichens. Lichenologist 1990, 22, 149-162.

43. Crittenden, P.D. Aspects of the ecology of mat-forming lichens. Rangifer 2000, 20, 127-139.

44. Yahr, R. Ecology and post-fire recovery of Cladonia perforata, an endangered Florida-scrub lichen. For. Snow Landsc. Res. 2000, 75, 339-356.

45. Roturier, S.; Bäcklund, S.; Sundén, M.; Bergsten, U. Influence of ground substrate on establishment of reindeer lichen after artificial dispersal. Silva Fenn. 2007, 41, 269-280.

46. Roturier, S.; Bergsten, U. Establishment of Cladonia stellaris after artificial dispersal in an unfenced forest in northern Sweden. Rangifer 2009, 29, 39-49.

47. Heinken, T. Dispersal patterns of terricolous lichens by thallus fragments. Lichenologist 1999, 31, 603-612.

48. Hilmo, O.; Ott, S. Juvenile development of the cyanolichen Lobaria scrobiculata and the green algal lichens Platismatia glauca and Platismatia norvegica in a boreal Picea abies forest. Plant Biol. 2002, 4, 273-280.

49. Scheidegger, C. Early development of transplanted isidioid soredia of Lobaria pulmonaria in an endangered population. Lichenologist 1995, 27, 361-374.

50. Kalwij, J.M.; Wagner, H.H.; Scheidegger, C. Effects of stand-level disturbances on the spatial distribution of a lichen indicator. Ecol. Appl. 2005, 15, 2015-2024.

51. Ahti, T. Taxonomic studies on reindeer lichens (Cladonia, subgenus Cladina). Ann. Bot. Soc. 1961, $32,1-160$.

52. Helle, T.; Aspi, J. Effects of winter grazing by reindeer on the vegetation. Oikos 1983, 40, 337343.

53. Scotter, G.W. Growth rates of Cladonia alpestris, C. mitis, and C. rangiferina in the Taltson River region Northwest Territories. Can. J. Bot. 1963, 41, 1199-1202.

54. Den Herder, M.; Kytöviita, M.M.; Niemela, P. Growth of reindeer lichens and effects of reindeer grazing on ground cover vegetation in a Scots pine forest and a subarctic heathland in Finnish Lapland. Ecography 2003, 26, 3-12.

55. Boudreault, C.; Zouaoui, S.; Drapeau, P.; Bergeron, Y.; Stevenson, S. Canopy openings created by partial cutting increase growth rates and maintain the cover of three Cladonia species in the Canadian boreal Forest. For. Ecol. Manag. 2013, 304, 473-481.

56. Södeström, L.; Jonsson, B. Spatial pattern and dispersal in the leafy hepatic Ptilidium pulcherrimum. J. Bryol. 1989, 15, 793-802.

57. Gustafsson, L.; Fiskesjö, A.; Hallingbäck, T.; Ingelög, T.; Pettersson, B. Semi-natural broadleaved woods in southern Sweden-Habitat factors of importance to some bryophyte species. Biol. Conserv. 1992, 59, 175-181.

58. Scheidegger, C.; Werth, S. Conservation strategies for lichens: Insights from population biology. Fungal Boil. Rev. 2009, 23, 55-66.

59. Kershaw, K.A.; Field, G.F. Studies on lichen-dominated systems. XV. The temperature and humidity profiles in a Cladina alpestris mat. Can. J. Bot. 1975, 53, 2614-2620. 
60. Jonsson, A.V.; Moen, J.; Palmqvist, K. Predicting lichen hydration using biophysical models. Oecologia 2008, 156, 259-273.

61. Kershaw, K.A.; Rouse, W.R. Studies on lichen-dominated systems. I. The water relations of Cladonia alpestris in spruce-lichen woodland in northern Ontario. Can. J. Bot. 1971, 49, 1389-1399.

62. Kershaw, K.A.; Rouse, W.R. Studies on lichen dominated systems. II. The growth pattern of Cladonia alpestris and Cladonia rangiferina. Can. J. Bot. 1971, 49, 1401-1410.

63. Sulyma, R.; Coxson, D.S. Microsite displacement of terricolous lichens by feather moss mats in late seral Pine-lichen woodlands of north-central British Columbia. Bryologist 2001, 104, 505-516.

64. Ahti, T.; Oksanen, J. Epigeic lichen communities of taiga and tundra regions. Vegetatio 1990, 86, $39-70$.

(C) 2014 by the authors; licensee MDPI, Basel, Switzerland. This article is an open access article distributed under the terms and conditions of the Creative Commons Attribution license (http://creativecommons.org/licenses/by/4.0/). 